\title{
PENERAPAN METODE CROSS SELLING PADA APLIKASI ONLINE ISMSHOP11 - BANDUNG
}

\author{
Michael $\mathrm{Ng}^{1}$ \\ Julianti Kasih ${ }^{2}$ \\ Program Studi S1 Teknik Informatika, Universitas Kristen Maranatha \\ Jl. Prof. Drg. Surya Sumantri 65 Bandung \\ Email : calm.michael@hotmail.com ${ }^{1}$ \\ julianti.kasih@it.maranatha.edu ${ }^{2}$
}

\begin{abstract}
ABSTRAK
Pada jaman millenial ini dituntut kecepatan dalam pengerjaan segala sesuatu. Untuk itu dibutuhkan alat bantu, sistem terkomputerisasi yang memiliki kelebihan, dalam kecepatan, keakuratan, serta efisiensi pengolahan data. Penerapan Sistem On line pada Ismshop11 dengan metode cross-selling yaitu cara merekomendasikan barang dengan tingkat penjualan yang tinggi, diharapkan dapat membantu konsumen. Dengan sistem ini pula diharapkan dapat mempermudah pengelolaan seluruh data penjualan, pembelian dan persedian barang, sehingga tujuan Ismhop11 dapat dicapai secara maksimal.
\end{abstract}

Kata Kunci : Sistem online, penjualan, pembelian, dan cross-selling

\section{PENDAHULUAN}

Perkembangan sistem informasi tidak lepas dari banyaknya kebutuhan terhadap informasi. Dinamika dari masyarakat yang semakin cepat seiring dengan perkembangan jaman dan teknologi memerlukan kualitas informasi yang akurat, cepat dan tepat. Untuk itu dibutuhkan suatu sistem terkomputerisasi yang dapat membantu masyarakat mendapatkan informasi dengan kualitas tersebut diatas. Untuk memenuhi kebutuhan, masyarakat jaman sekarang banyak mengunakan fasilitas pembelian barang secara on line, sehingga tidak heran sistem penjualan online menjadi trend yang digunakan oleh para pedagang.

Toko Ismshop11 merupakan sebuah usaha dagang jersey bola dan sepatu futsal. Dengan banyaknya barang-barang yang ada, hal ini tentunya akan membutuhkan pengelolaan data pembelian dan penjualan. Pada Ismshop11 untuk pengelolaan data supplier, data barang, data penjualan, dan data pembelian masih di lakukan secara manual dan tidak terintegrasi satu dengan yang lainnya. Kesulitan lain yang dihadapi terkadang kertas yang digunakan untuk mencatat transaksi penjualan dan pembelian hilang, dan perhitungan penjualan dan pembelian tiap bulan memakan waktu yang lama. Pengolahan data pada persediaan gudang di Toko Ismshop11 pun masih manual, artinya dari segi pencatatan barang yang tersedia masih menggunakan buku laporan persediaan. Masalah lainnya lagi, tidak semua stok barang di catat di dalam buku laporan persediaan. Ada suatu barang yang tidak termonitor jumlah stoknya, 
sehingga ketika terjadi penjualan barang pemilik toko harus melihat berapa banyak stok yang di miliki ke gudang. Itu sangat memakan waktu dan membuat pembeli menunggu lama.

Untuk mengatasi hal itu, dibuatlah sebuah aplikasi khusus yang digunakan untuk mengelola dan mencatat berbagai transaksi penjualan,pembelian dan persediaan pada Toko Ismshop11, juga untuk membantu pembeli memilih barang yang dijual maka digunakan metode crossselling. Metode ini akan memberikan rekomendasi produk yang menjadi pilihan terbanyak dari para pembeli. Aplikasi ini dibangun dengan menggunakan pemrograman PHP dan database MySQL. Dengan adanya aplikasi ini diharapkan dapat membantu pencatatan data keluar masuk barang pada Toko Ismshop11 dan pengelolaan data penjualan dan pembelian. Sehingga aplikasi khusus yang di buat dapat lebih meningkatkan efektivitas kerja serta menyediakan informasi dengan cepat dan akurat bagi konsumen.

Tujuan pembahasan adalah sebagai berikut:

1. Membuat suatu sistem pengelolaan data barang, data supplier, data pelanggan, transaksi penjualan, transaksi pembelian dan persediaan pada Ismshop11.

2. Menghasilkan suatu sistem yang dapat merekomendasikan produk-produk yang banyak dibeli oleh konsumen Ismshop11 dengan menerapkan metode cross selling.

3. Menghasilkan suatu sistem yang dapat menghasilkan laporan-laporan penjualan, pembelian dan persediaan berdasarkan waktu yang ditentukan

\section{KAJIAN TEORI}

Di dalam penelitian ini, terdapat beberapa teori yang dijadikan landasan dalam penelitian ini. Berikut ini adalah teori-teori yang digunakan:

\section{A. E-Commerce}

E-commerce (electronic commerce) merupakan perdagangan elektronik dimana untuk transaksi perdagangan baik membeli maupun menjual dilakukan melalui elektronik pada jaringan internet. Keberadaan e-commerce sendiri dalam internet dapat dikenali melalui adanya fasilitas pemasangan iklan, penjualan, dan servicesupport terbaik bagi seluruh pelanggannya dengan menggunakan sebuah toko online berbentuk web yang setiap harinya beroperasi selama 24 jam. [1] E-Commerce dibedakan berdasarkan sistem transaksinya dibagi menjadi beberapa klasifikasi:

- BusinesstoBusiness

Transaksi ini terjadi jika pembeli membeli dalam jumlah besar untuk dijual kembali.

- Business to Consumer

Jenis transaksi ini merupakan transaksi antara penjual dan pembeli yang tidak menjual barangnya kembali tetapi digunakan sendiri.

- Customer to Customer

Jenis transaksi ini merupakan transaksi antara pembeli yang tidak berniat menjual barangnya kembali, dan penjual yang hanya menyediakan beberapa barang miliknya.

- Customer to Business

Jenis transaksi ini merupakan transaksi antara penjual perseorangan kepada suatu perusahaan/ organisasi. 


\section{B. Penjualan}

Penjualan merupakan kegiatan yang dilakukan oleh seorang penjual dalam menjual barang atau jasa dengan tujuan akan memperoleh laba dari adanya transaksi-transaksi tersebut dan penjualan dapat diartikan sebagai pengalihan atau pemindahan hak kepemilikan atas barang atau jasa dari pihak penjual kepada pihak pembeli. [2]

Kegiatan menjual barang yang diproduksi sendiri atau dibeli dari pihak lain untuk dijual kembali kepada konsumen baik secara kredit maupun tunai. Jadi secara umum penjualan pada dasarnya terdiri dari dua jenis yaitu penjualan tunai dan kredit. Penjualan tunai terjadi apabila penyerahan barang atau jasa segera diikuti dengan pembayaran dari pembeliannya, sedangkan penjualan kredit memiliki tenggang waktu antara pada saat penyerahan barang atau jasa dalam penerimaan pembelian.

Keuntungan dari penjualan tunai adalah hasil dari penjualan tersebut langsung terealisir dalam bentuk kas. Sedangkan dalam rangka memperbesar volume penjualan, umumnya perusahaan menjual produknya secara kredit. Penjualan kredit tidak segera menghasilkan pendapatan kas, tapi kemudian menimbulkan piutang. Kerugian dari penjualan kredit adalah timbulnya biaya administrasi piutang dan kerugian akibat piutang tak tertagih. [2]

\section{Pembelian}

Pembelian merupakan salah satu fungsi yang penting dalam berhasilnya operasi suatu perusahaan. Fungsi ini dibebani tanggung jawab untuk mendapatkan kuantitas dan kualitas bahan-bahan yang tersedia pada waktu dibutuhkan dengan harga yang sesuai dengan harga yang berlaku. Pengawasan perlu dilakukan terhadap pelaksanaan fungsi ini, karena pembelian menyangkut investasi dana dalam persediaan dan kelancaran arus bahan ke dalam pabrik. [3]

Sistem pembelian adalah suatu sistem yang dibuat menurut pola terpadu untuk melaksanakan pembelian dalam rangka mendapatkan barang. dalam mengambil keputusan mengenai transaksi-transaksi yang terdapat dalam kegiatan pembelian, manajemen perusahaan memerlukan banyak pertimbangan dari beberapa faktor yang dapat mempengaruhi aktivitas perusahaan yang harus dilakukan. Sehingga dalam mengefektifkan dan mengefisiensikan jalanya proses transaksi pembelian yang mengatur dengan baik dan pengawasan yang baik pula.

\section{Cross Selling}

Cross-selling merupakan metode yang menjual produk-produk tambahan dan jasa kepada pelanggan yang telah sepakat untuk membeli atau telah membeli. Berikut ini adalah cara yang digunakan untuk mengaplikasikan cross-selling adalah:

1. Mengambil data barang apa saja yang telah terjual bersama barang yang sedang dilihat

2. Mengakumulasi barang yang paling banyak dibeli bersamaan dengan barang yang sedang dilihat

3. Mengurutkan berdasarkan barang yang paling banyak dibeli

4. Mengambil 3 barang teratas untuk direkomendasikan kepada pelanggan [4]

\section{E. Persediaan}

Menurut Ristono, persediaan (inventori) adalah barang-barang yang disimpan untuk digunakan atau di jual pada masa yang akan datang. [5] 
Sedangkan menurut Alexandri, Persediaan merupakan suatu aktiva yang meliputi barang-barang milik perusahaan dengan maksud untuk di jual dalam suatu periode usaha tertentu atau persediaan barang-barang yang masih dalam pengerjaan atau proses produksi ataupun persediaan bahan baku yang menunggu penggunaannya dalam proses produksi. [6]

\section{ANALISIS DAN PERANCANGAN SISTEM}

\section{A. Proses Bisnis Penjualan}

Proses penjualan barang pada Toko Ismshop11 terdapat pada Gambar 3.1 Proses Bisnis Penjualan:

1. Pelanggan datang ke toko dan memilih barang.

2. Pelanggan membawa barang yang sudah dipilih ke pegawai.

3. Pegawai akan melakukan pencatatan barang yang dibeli pelanggan dan melakukan perhitungan total pembelian.

4. Pelanggan melakukan pembayaran.

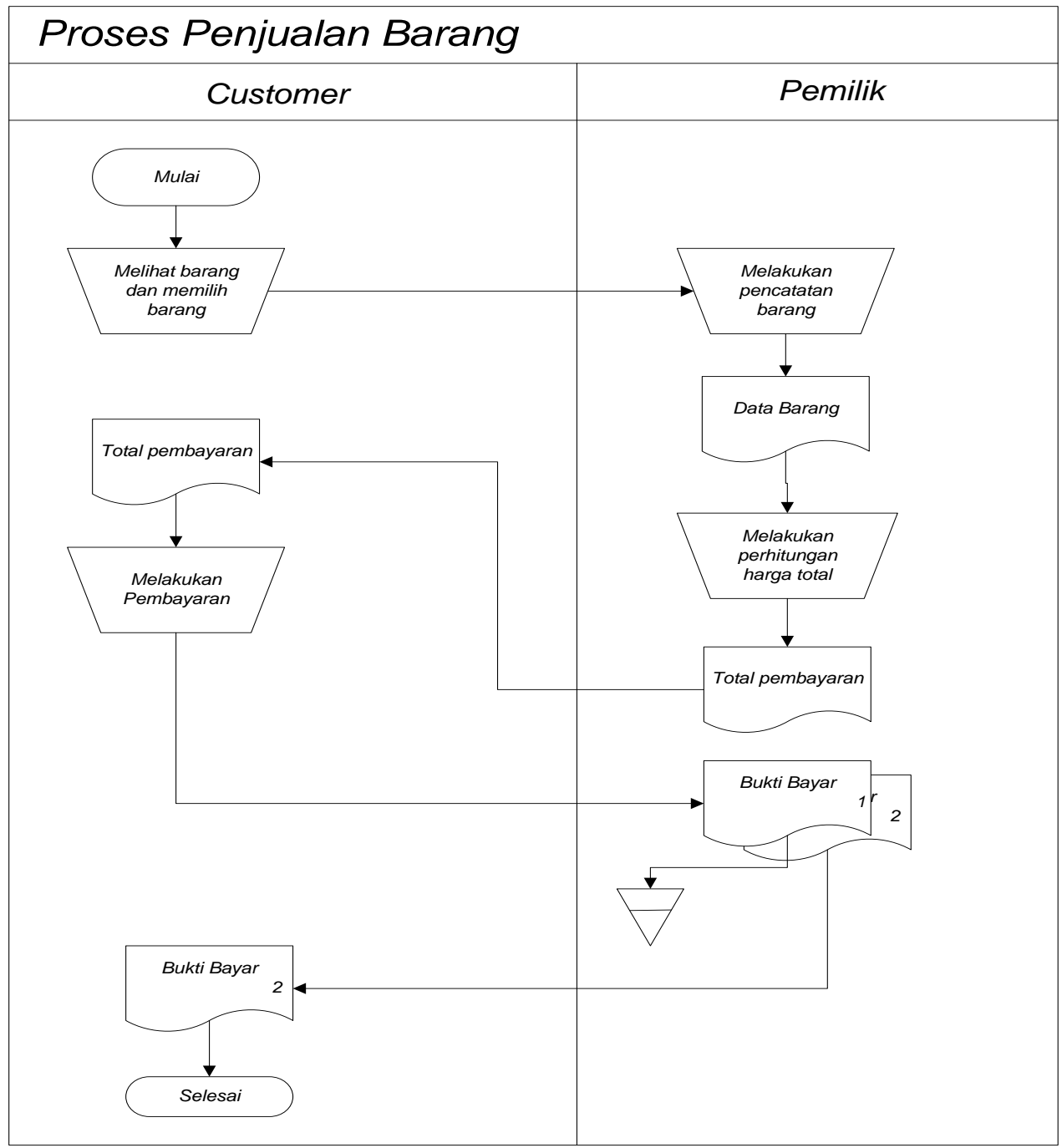

Gambar 1. Proses Penjualan Barang 


\section{B. Proses Bisnis Pembelian}

Proses pembelian barang pada Toko Ismshop11 terdapat pada Gambar 2 Proses Bisnis Pembelian :

1. Pemilik memesan barang melalui telepon kepada supplier dan supplier mencatat pesanan lalu melakukan perhitungan harga total barang kemudian mengirimkan barang ke gudang.

2. Gudang memberikan pemberitahuan kepada pemilik bahwa barang sudah diterima lalu pemilik melakukan pembayaran.

3. Jika pemilik membayar lunas maka pemilik dan supplier akan menyimpan bukti pembayaran, jika membayar dengan credit maka pemilik dan supplier akan mencatat sisa pembayaran

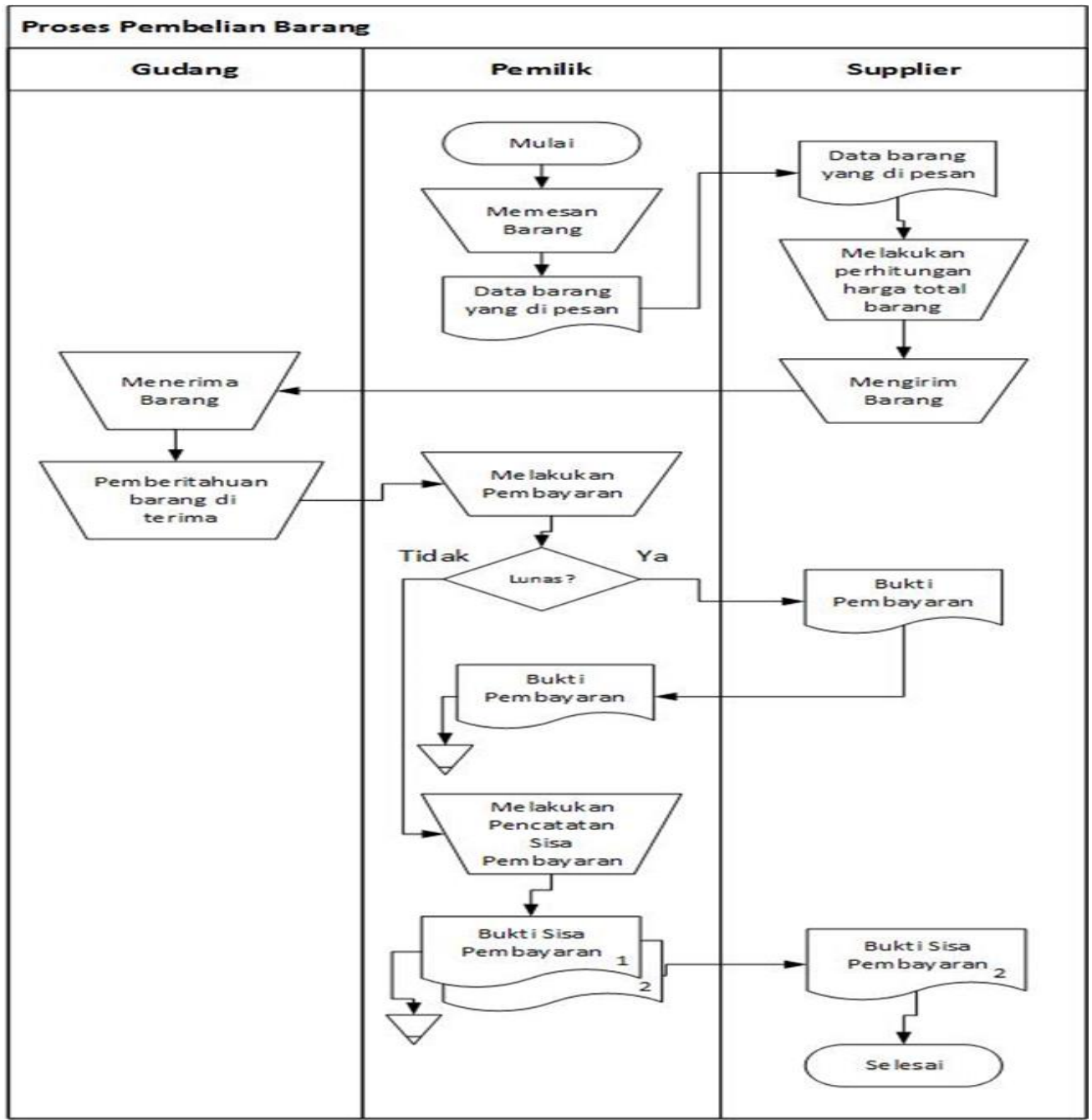

Gambar 1. Proses Bisnis Pembelian 


\section{ERD (Entity Relationship Diagram)}

Berikut ini adalah Entity Relationship Diagram(ERD) dari Sistem E-Commerce Toko Ismshop:

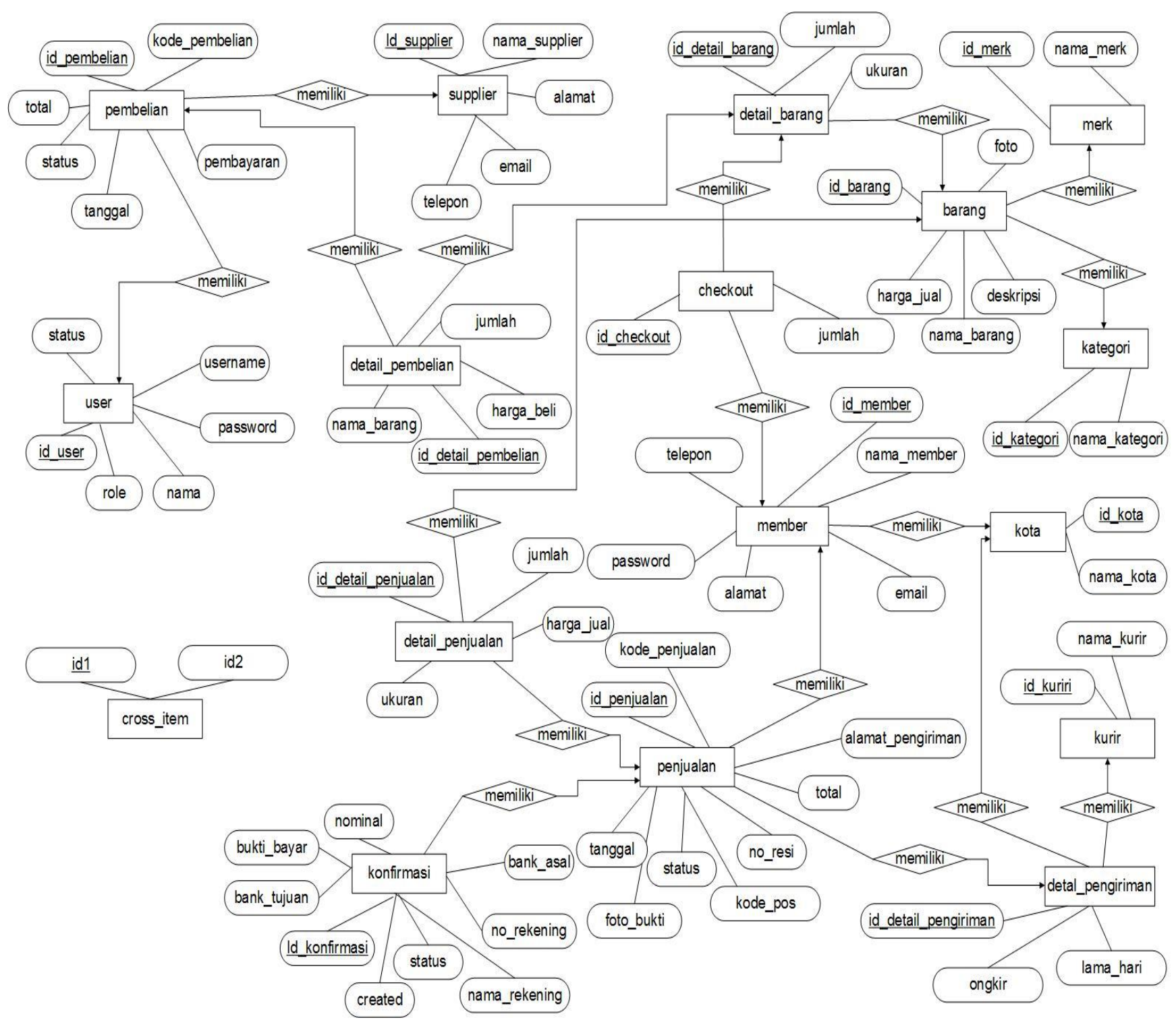

Gambar 2. Gambar Entity Relationship Diagram

\section{Use Case Diagram}

Berikut ini adalah pemodelan dengan menggunakan usecase diagram.:

1. Use Case Diagram Sistem E-Commerce 
Pada Gambar 4 merupakan use case diagram dari systeme-commerce Toko Ismshop11. Terdapat 3 aktor, yaitu pemilik, admin dan member. Untuk pengguna sebagai pemilik dapat mengelola member, pembelian, user, barang, penjualan, pengiriman, supplier dan laporan. Sedangkan pengguna sebagai admin dapat mengelola penjualan, barang, supplier, member dan pengiriman. Sedangkan pengguna sebagai member dapat melakukan pembelian dan mengelola data member.

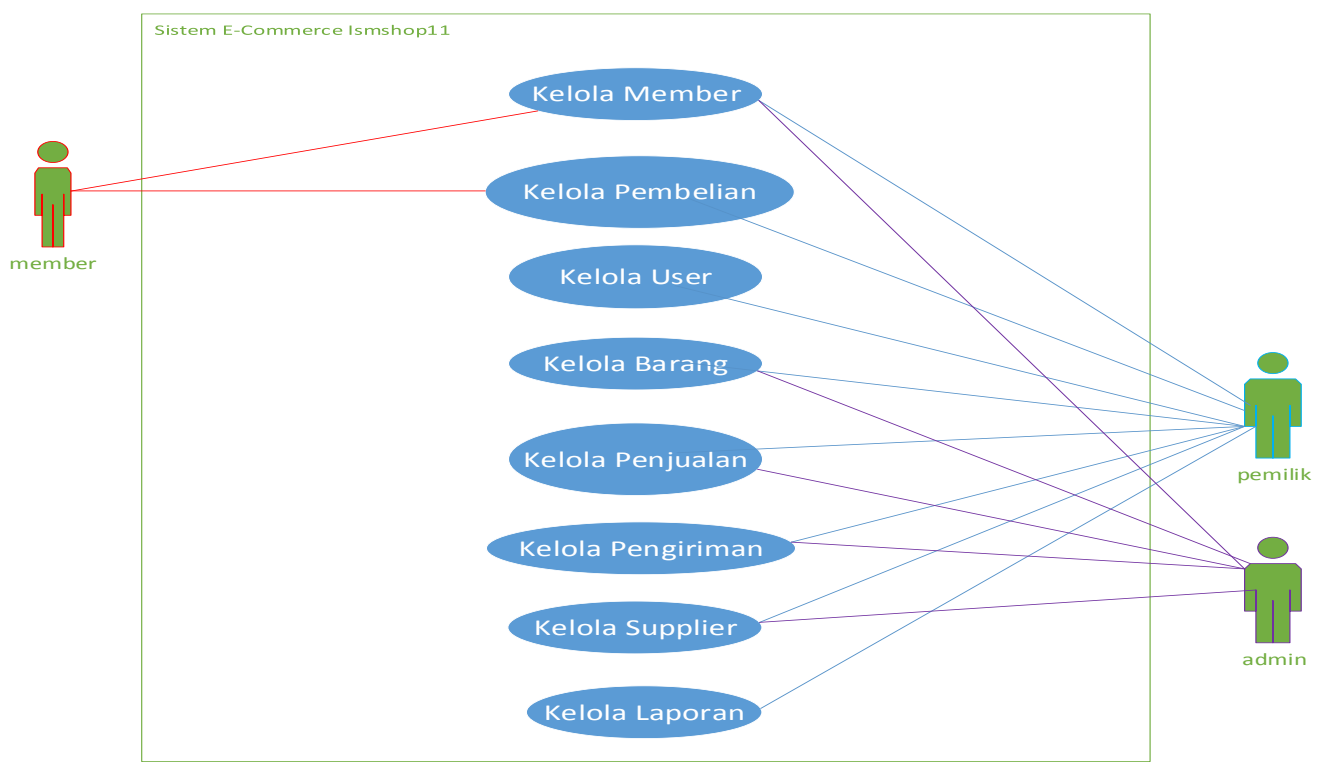

Gambar 3. Use Case E-Commerce

2. Use Case Diagram Kelola Pembelian oleh Member

Pada Gambar 5 merupakan use case diagram kelola pembelian member. Aktor sebagai member dapat mencari barang, melihat list barang, melihat detail barang, menambah ke keranjang, melihat checkout, menambah data penerima, mengedit checkout, delete checkout, menambah konfirmasi pembayaran, melihat list transaksi, menerima barang dan melihat detail pembelian. 


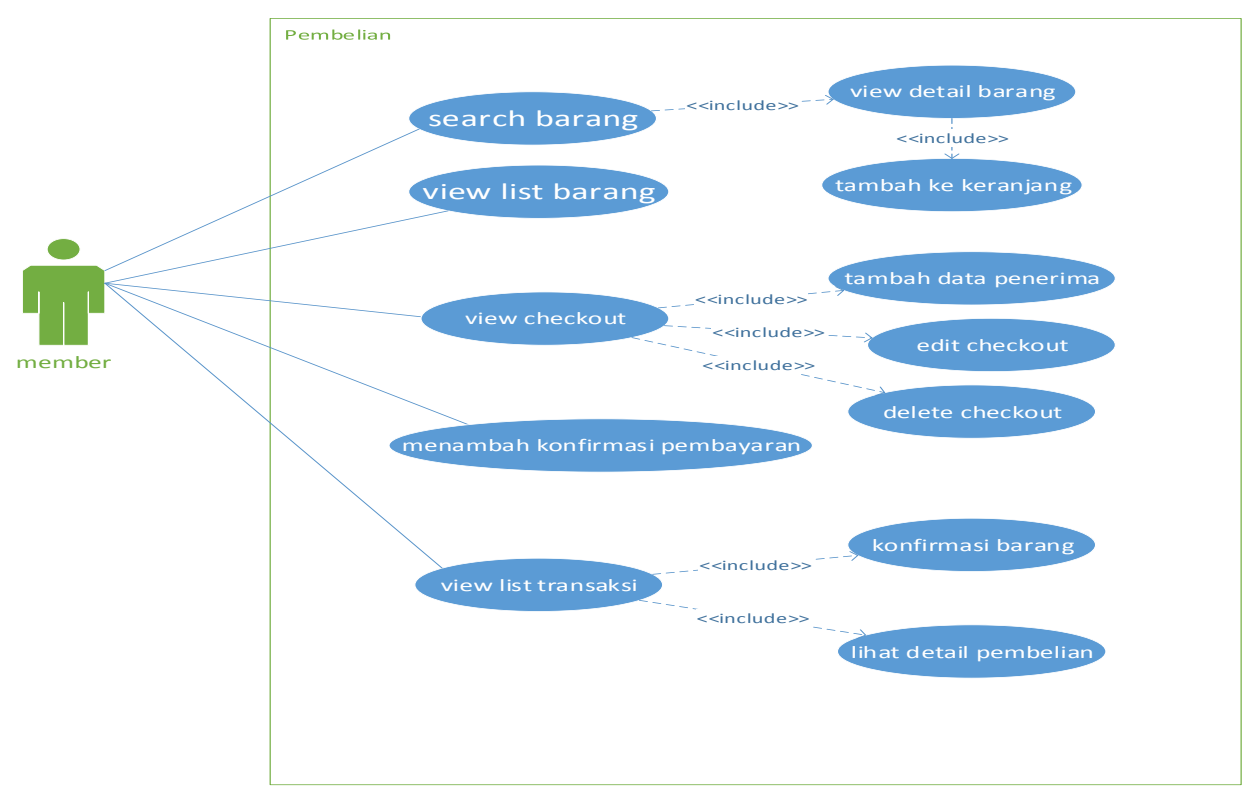

Gambar 4. Use Case Diagram Kelola Pembelian oleh Member

\section{Use Case Diagram Kelola Pembelian oleh Admin}

Pada Gambar 6 ini merupakan use case diagram kelola pembelian admin. Aktor yang dapat mengakses menu ini hanya pemilik. Pemilik melakukan menambah data barang beli, melihat list barang beli, delete barang beli, search barang beli, menambah konfirmasi pembelian dan melihat faktur.

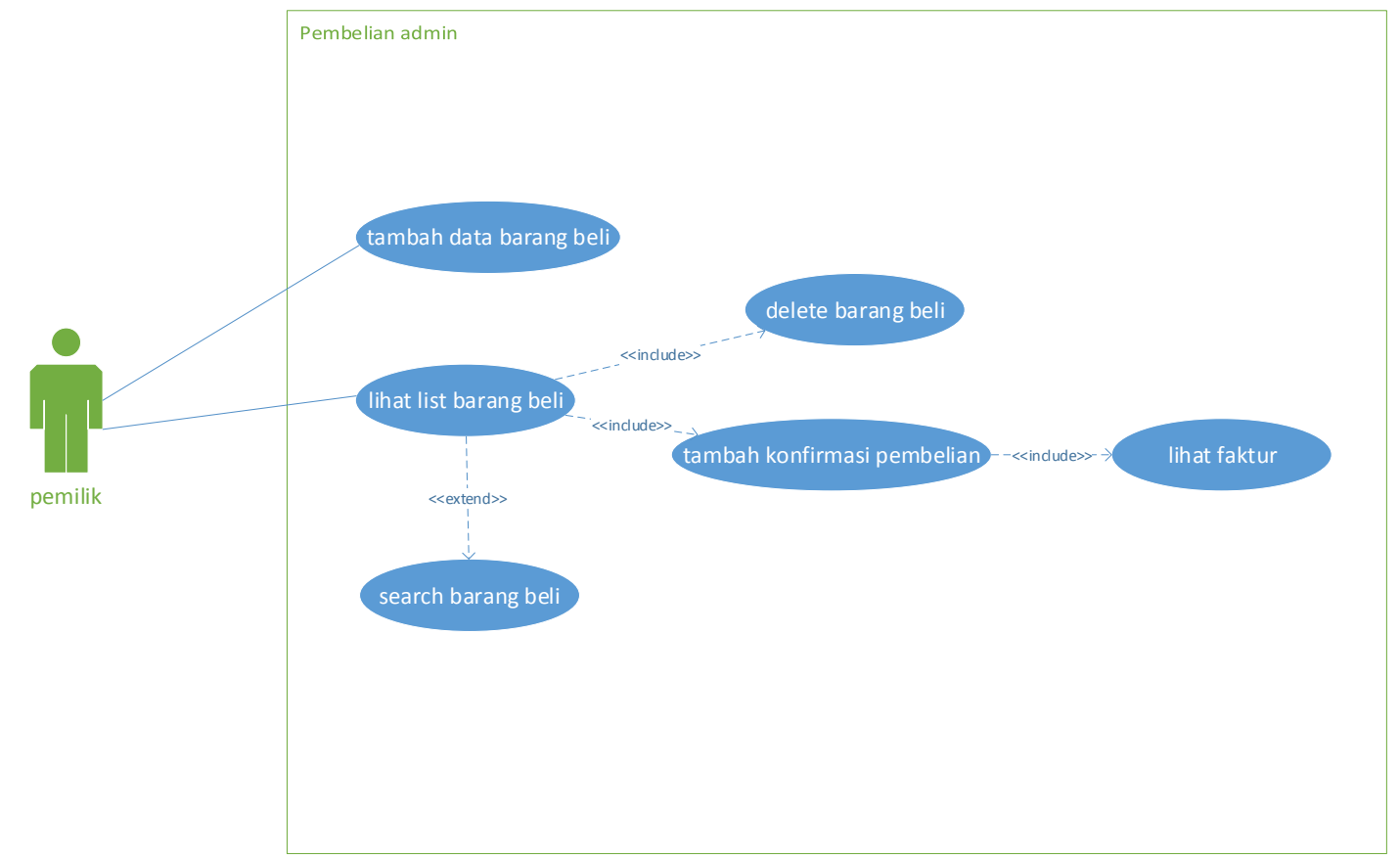

Gambar 5. Use Case Diagram Kelola Pembelian oleh Admin 


\section{Use Case Diagram Kelola Barang}

Pada Gambar 7 merupakan use case diagram kelola barang. Aktor pemilik dan admin dapat mengakses menu barang yang terdiri dari data barang, merk dan kategori. Jika pemilik memilih data barang maka pemilik dapat menambah barang, melihat list barang, mengedit data barang dan melihat detail barang. Jika pemilik memilih merk maka pemilik dapat menambah merk dan melihat list merk kemudian mengubah data merk dan mencari data merk. Jika pengguna memilih kategori maka pemilik dapat menambah kategori dan melihat list kategori kemudian mengubah data kategori dan mencari data kategori.

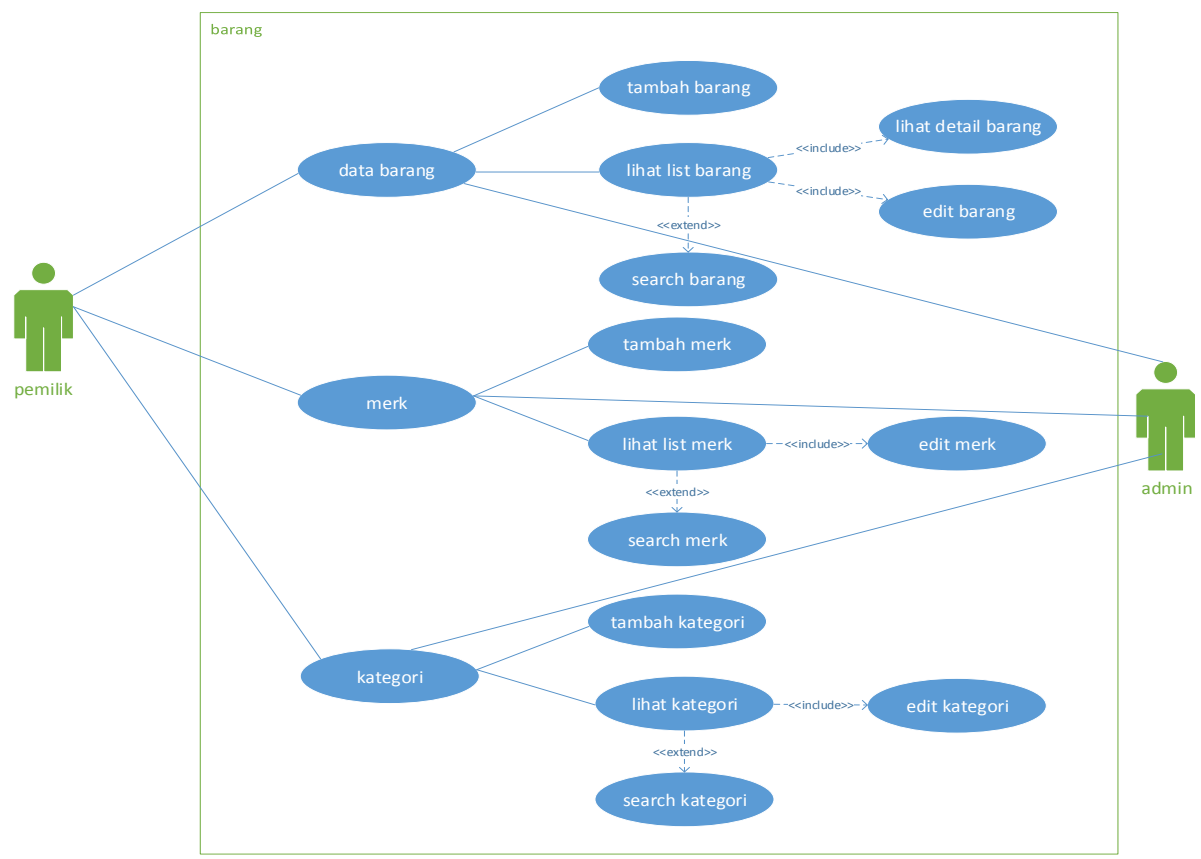

Gambar 6. Use Case Diagram Kelola Barang

\section{Use Case Diagram Kelola Penjualan}

Pada Gambar 8 merupakan use case diagram kelola penjualan. Aktor pemilik dan admin dapat mengakses menu penjualan yang terdiri dari konfirmasi penjualan dan list penjualan. Pada use case konfirmasi penjualan aktor dapat menerima konfirmasi, menolak konfirmasi dan mencari data konfirmasi. Sedangkan pada list penjualan aktor dapat melihat detail penjualan, mencari data penjualan dan menambahkan no resi. 


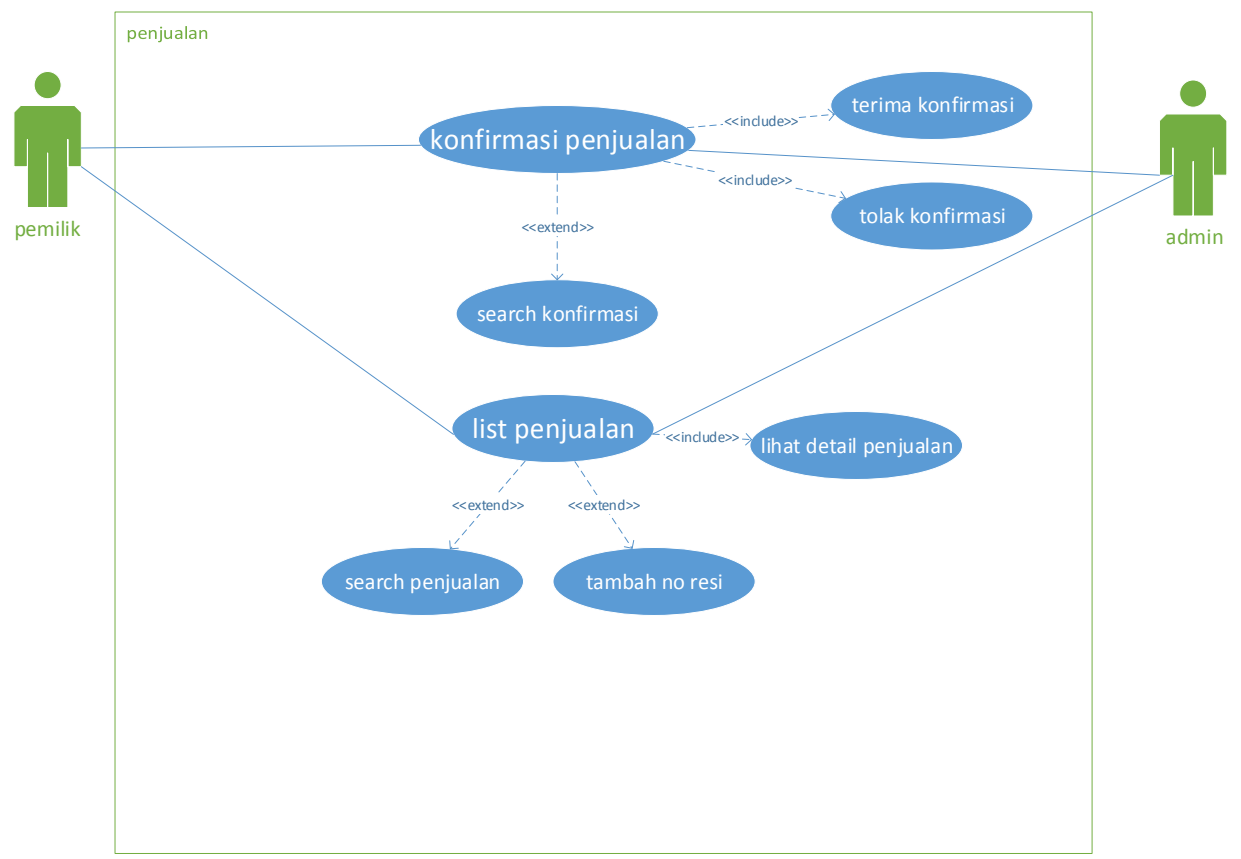

Gambar 7. Use Case Diagram Kelola Penjualan

\section{E. Activity Diagram}

Gambar 9 merupakan activity diagram rekomendasi crossselling. Pertama user milih barang. Kemudian system mengambil data barang yang dipilih dan mencari data barang yang paling banyak dibeli bersamaan dengan barang yang sedang dipilih. Setelah itu system menyimpan hasil id barang dan jumlah terjualnya, kemudian system mensorting data berdasarkan banyaknya jumlah barang yang terjual. Terakhir system menampilkan data barang yang direkomendasikan berdasarkan urutan sorting yang paling banyak terjual.

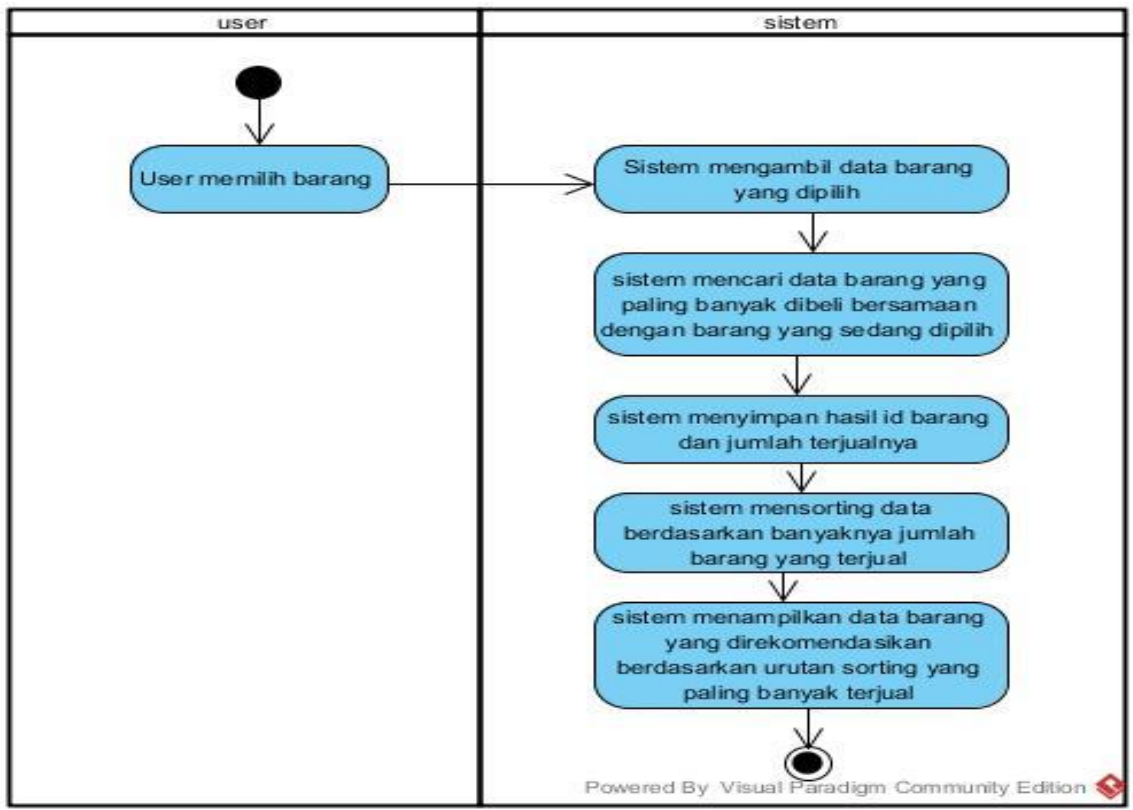

Gambar 8. Activity Diagram Cross Selling 


\section{IMPLEMENTASI}

\section{A. Tampilan Halaman Admin}

1. Tampilan Halaman Konfirmasi Penjualan

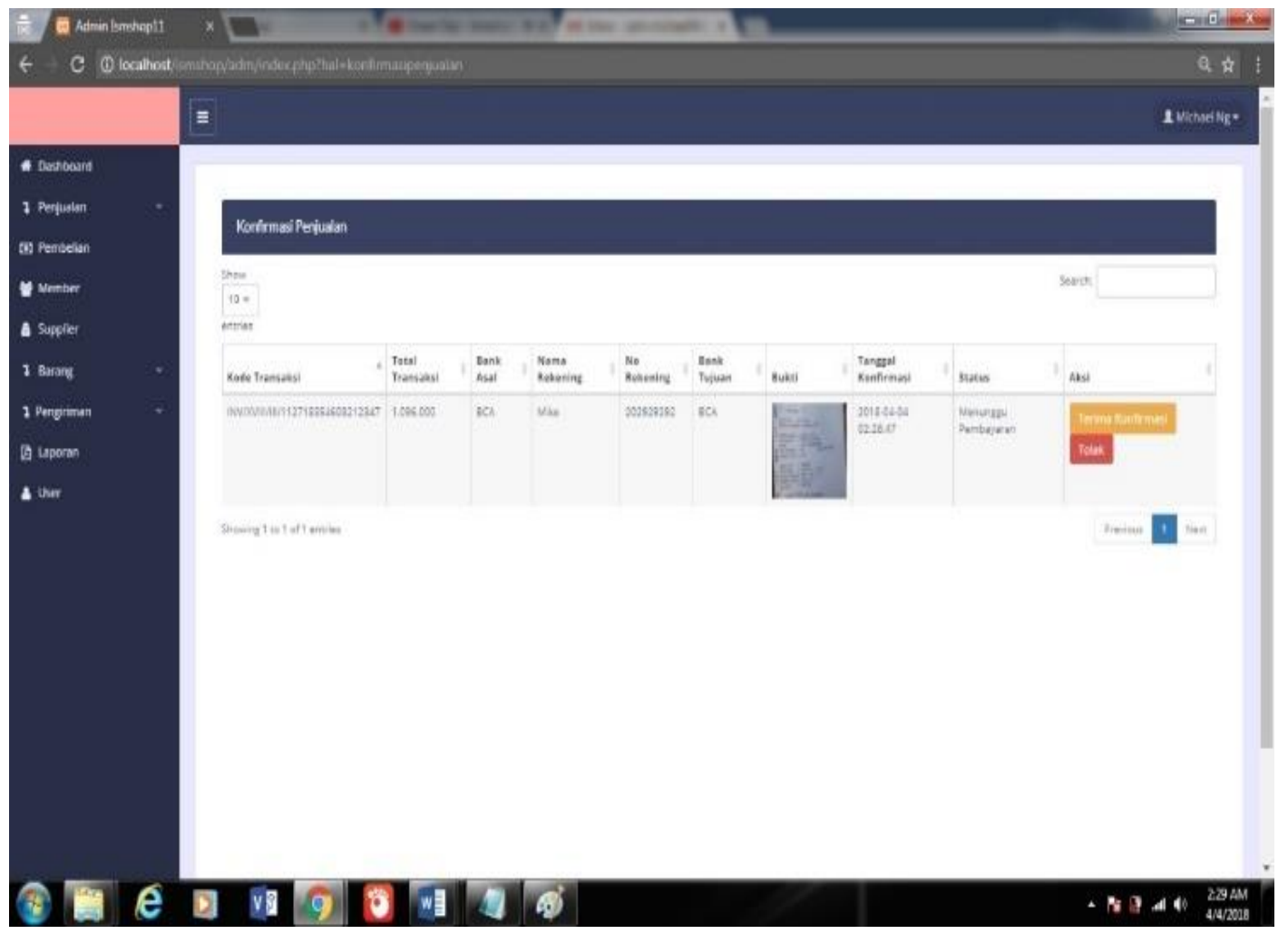

Gambar 9. Tampilan Halaman Konfirmasi Penjualan

Gambar 10 merupakan tampilan halaman konfirmasi penjualan. Pada Halaman ini terdapat tabel konfirmasi penjualan yang berisi data dari member yang telah melakukan pembayaran dan terdapat tombol terima konfirmasi dan tolak. Jika pengguna memilih tombol terima konfirmasi maka sistem akan mengirimkan email pemesan sedang di proses. Jika pengguna memilih tombol tolak maka system akan mengirimkan email konfimasi pembayaran ditolak. 
2. Tampilan Halaman List Penjualan

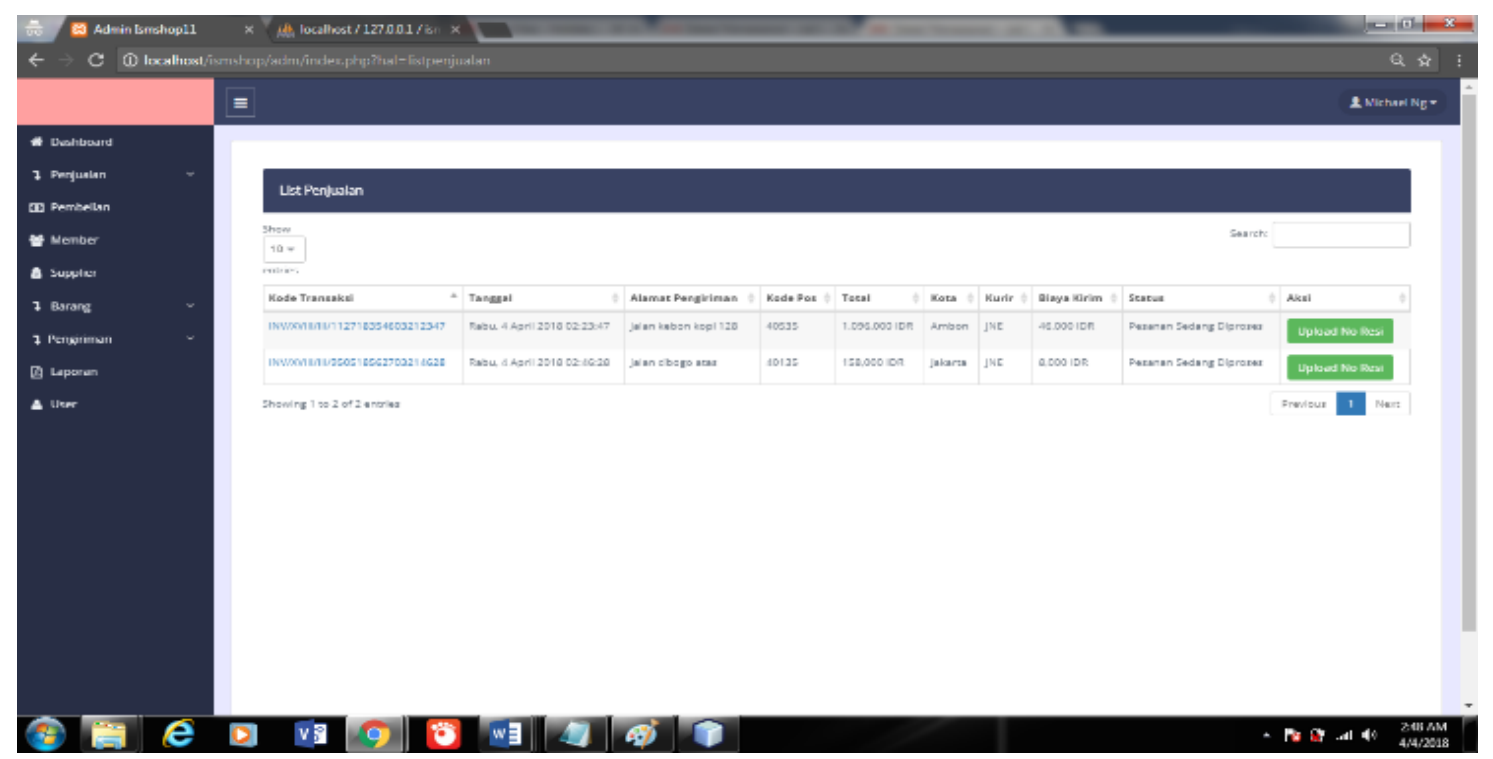

Gambar 10. Tampilan Halaman List Penjualan

Gambar 11 merupakan tampilan halaman list penjualan. Pada halaman ini terdapat tabel list penjualan. Jika pengguna memilih kode transaksi maka akan muncul modal detail penjualan.Terdapat juga tombol aksi yang dapat digunakan untuk mengupload no resi yang status penjualannya pesanan sedang diproses.

\section{Tampilan Halaman Pembelian}

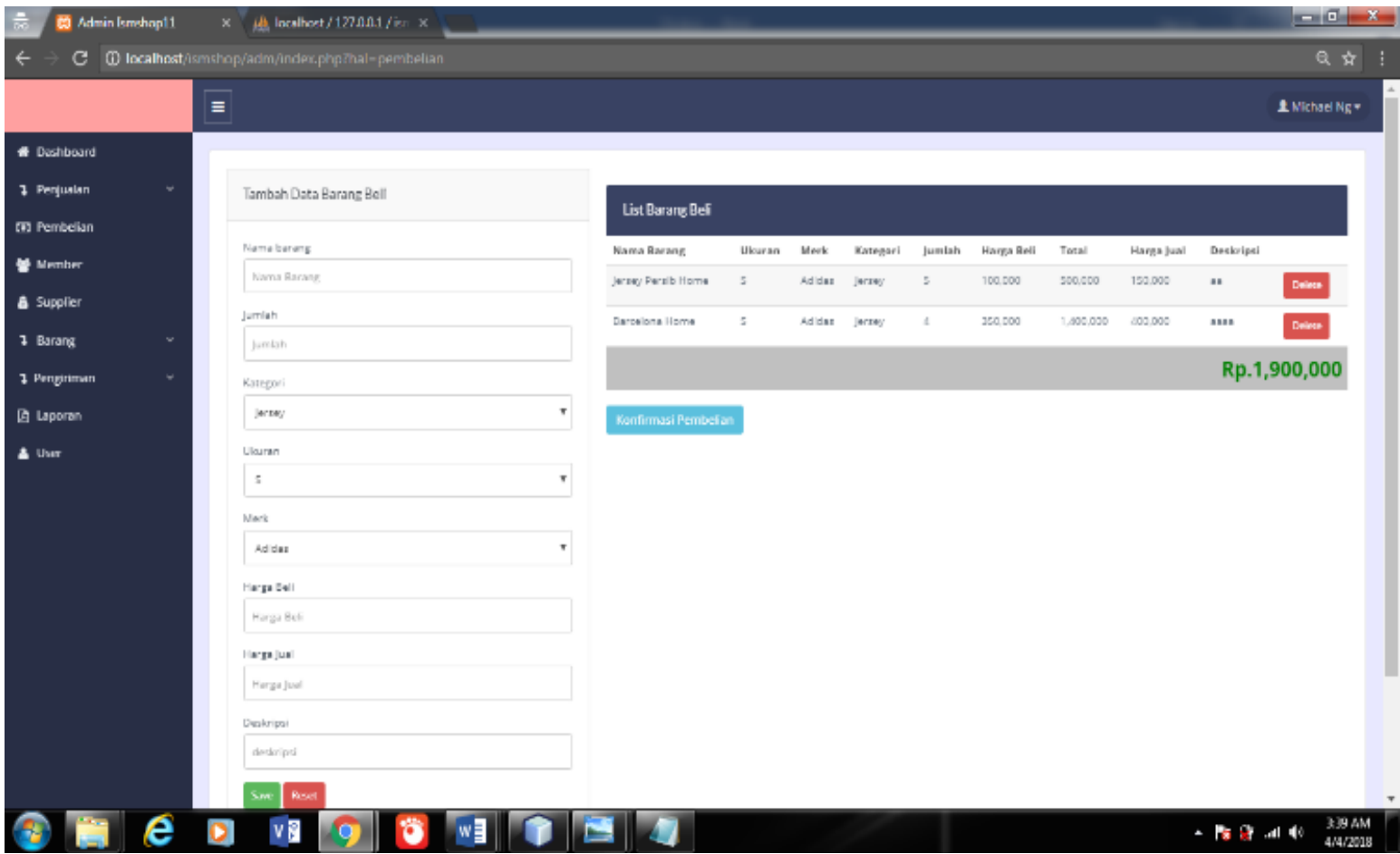

Gambar 11. Tampilan Halaman Pembelian 
Gambar 12 merupakan tampilan halaman pembelian. Pada halaman ini terdapat form tambah pembelian dan tabel list barang beli. Pada form tambah pembelian pengguna dapat menambahkan barang yang ingin di beli, jika barang yang sudah ada maka sistem akan memunculkan data barang tersebut dan pengguna tinggal memasukkan data jumlah, memilih ukuran, memasukkan data harga beli dan harga jual. Pada tabel list barang beli terdapat list barang yang telah ditambahkan pada form tambah data barang beli. Pada tabel list barang beli terdapat tombol delete yang berguna untuk menghapus barang yang telah ditambahkan pada form tambah data barang beli. Dibawah tabel list barang terdapat tombol konfirmasi pembelian yang berguna untuk menampilkan form konfimasi pembelian.

\section{Tampilan Faktur Pembelian}

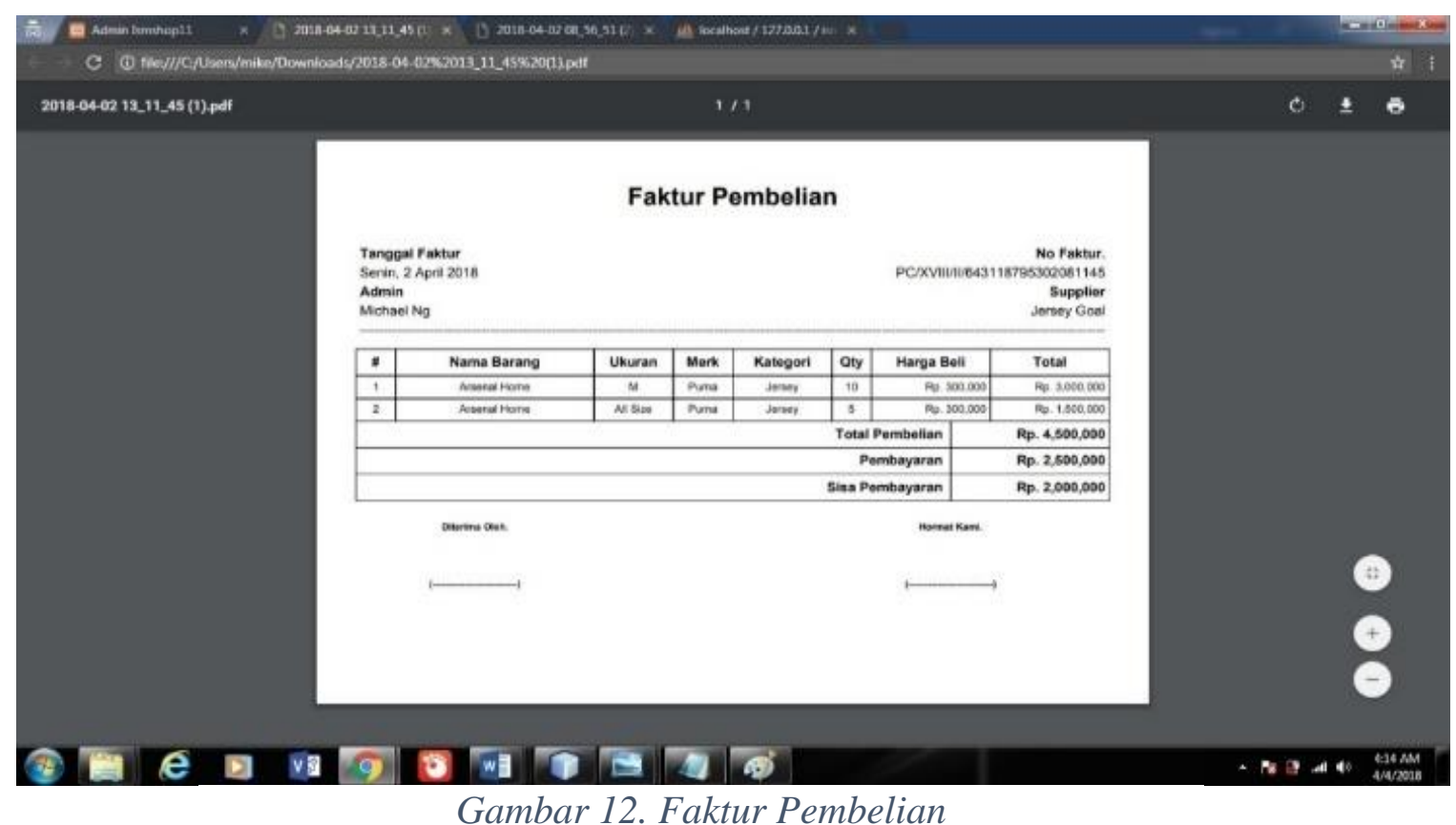

Gambar 13 merupakan tampilan faktur pembelian. Faktur pembelian ini muncul ketika user telah selasai melakukan pembayaran.Pada faktur ini terdapat tanggal pembuatan faktur, pembuatan faktur oleh siapa, nomor faktur, pembelian pada supplier apa dan data barang apa saja yang dibeli, dan di sini juga terdapat jumlah pembayaran yang dilakukan dan sisa pembayaran yang belum dilunasi. 
5. Tampilan Halaman Lihat Produk

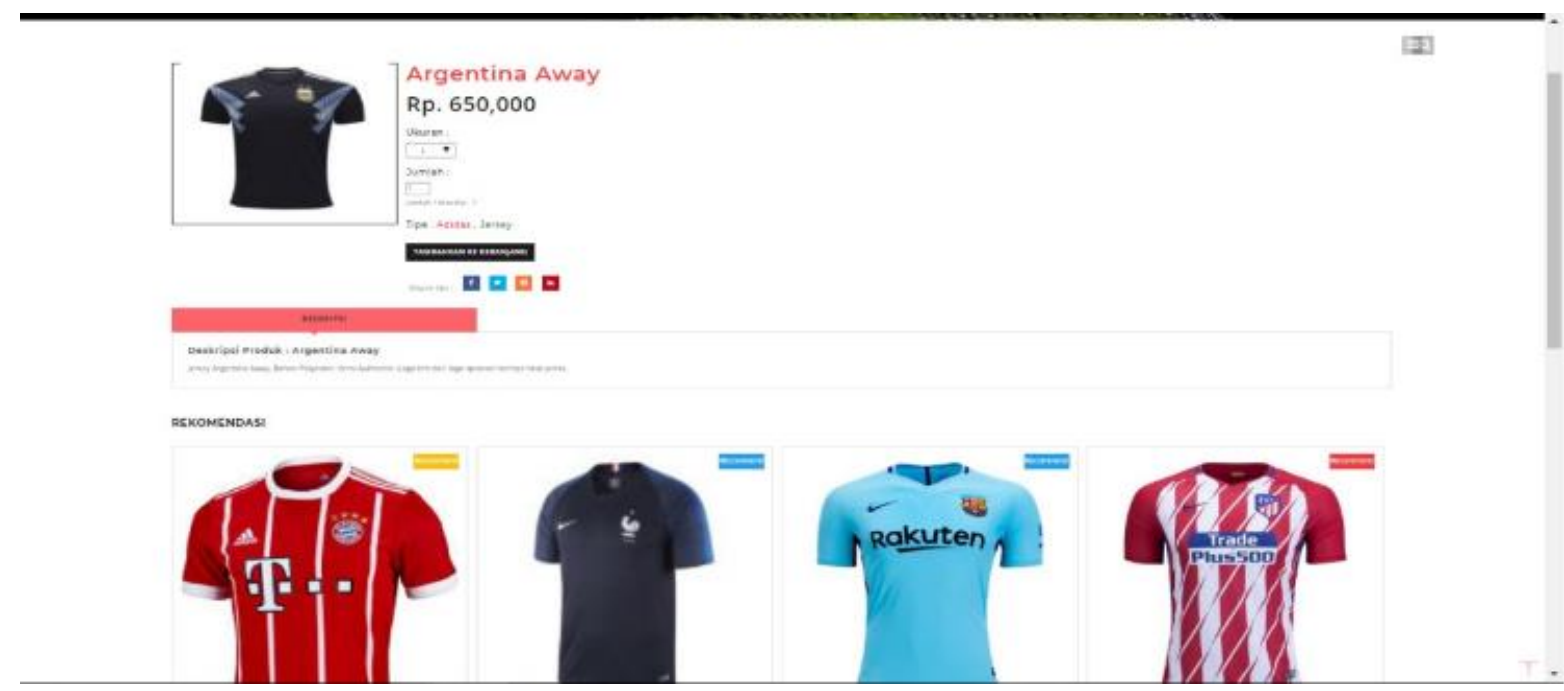

Gambar 13. Tampilan Halaman Lihat Produk

Gambar 14 merupakan tampilan halaman lihat produk. Pada halaman ini member dapat melihat detail produk, menambahkan ke keranjang dan melihat hasil rekomendasi cross selling produk yang dilihat.Rekomendasi cross selling yang didapat ini merupakan hasil dari sorting yang dilakukan system terhadap barang yang biasa dibeli bersamaan dengan barang lain yang dibeli oleh pelanggan lain.

6. Tampilan Halaman Checkout

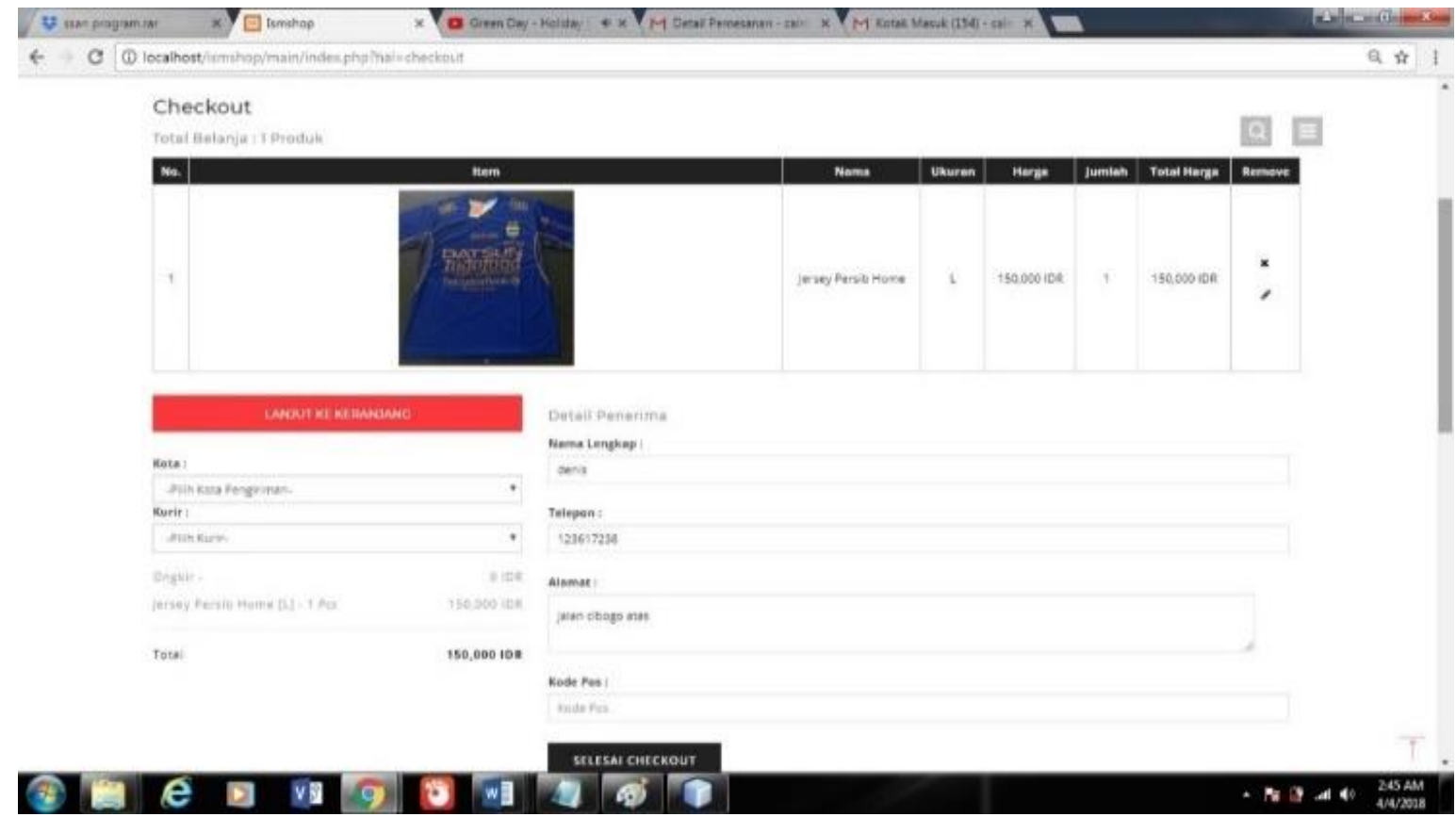

Gambar 14. Tampilan Halaman Checkout 
Gambar 15 merupakan tampilan halaman checkout. Pada halaman ini terdapat list barang yang dibeli, detail pengiriman, dan form detail penerima. Member dapat memilih kota dan kurir yang diinginkan untuk melihat ongkos kirim barang. Member dapat mengisi detail penerimaan barang. Setelah mengisi data tersebut member dapat memilih tombol selesai checkout untuk melakukan pesanan. System akan mengirimkan emaildetail pemesanan dan menunggu pembayaran.

\section{SIMPULAN DAN SARAN}

\section{A. Simpulan}

Kesimpulan yang dapat diambil berdasarkan pada tujuan yang telah disampaikan di bab 1 adalah sebagai berikut:

1. Sistem pada aplikasi yang dibuat memiliki fitur yang dapat mengelola data barang, supplier, pelanggan, transaksi penjualan, transaksi pembelian dan persediaan pada Ismshop11.

2. Sistem pada aplikasi yang dibuat untuk merekomendasikan produk-produk yang paling diminati pada Ismshop11 dengan menerapkan metode cross-selling.

3. Sistem pada aplikasi yang dibuat untuk menghasilkan laporan-laporaa dari hasil pengolahan data transaksi penjualan, data transaksi pembelian, data persedian pada Ismshop11 berdasarkan waktu yang ditentukan

\section{B. Saran}

Saran yang dapat disampaikan untuk mengembangkan aplikasi yang semakin baik adalah sebagai berikut:

1. Perlu adanya pengembangan aplikasi live chat antara member dan admin agar member dapat mendapatkan informasi secara cepat dan tepat

2. Memberikan promosi-promosi yang dapat menarik minat pelanggan seperti memberikan voucher diskon.

\section{DAFTAR PUSTAKA}

[1] R. Tantra, Manajemen Proyek Sistem Informasi, Bagaimana Mengelola Proyek Sistem Informasi Secara Efektif dan Efesien, Andi Publisher, 2012.

[2] A. B. B. Ladjamudin, Analisis dan Desain Sistem Informasi, Yogyakarta: Graha Ilmu, 2013.

[3] I. Jacobson, I. Spence and K. Bittner, Use Case 2.0, Global Consulting Service, 2011. 
[4] R. V. Imbar and D. Gunawan, "Aplikasi Penjualan Komputer dengan Metode Crossseling dan Upselling Dilengkapi Algoritma Greedy Dalam Pengambilan Keputusan," Jurnal Sistem Informasi, vol. 8, pp. 95-113, 2013.

[5] A. Ristono, Manajemen Persediaan edisi I, Yogyakarta: Graha Ilmu, 2009.

[6] M. B. Alexandri, Manajemen Keuangan Bisnis dan Soal, Bandung: Alfabeta, 2009. 